\title{
ANTIOXIDANT POTENTIAL OF Psidium guinnensis Sw. JAM DURING STORAGE ${ }^{1}$
}

\author{
Clarissa Damiani², Flávio Alves da Silva², Eduardo Ramirez Asquieri ${ }^{3}$, \\ Moacir Evandro Lage ${ }^{4}$, Eduardo Valério de Barros Vilas Boas ${ }^{5}$
}

\section{RESUMO \\ POTENCIAL ANTIOXIDANTE DE \\ GELEIA DE ARAÇÁ DURANTE O ARMAZENAMENTO}

A geleia de araçá é uma alternativa promissora de expansão do consumo deste fruto, além de agregar valor ao mesmo e promover a divulgação dos frutos do Cerrado brasileiro. Assim, o objetivo deste trabalho foi estudar as características físicas e químicas da geleia de araçá e avaliar a presença e comportamento dos compostos antioxidantes e cor, durante 12 meses de armazenamento. Os resultados obtidos da composição centesimal, açúcares, fibras, pectina e consistência mostraram que o uso do araçá foi adequado para a produção de geleias e que o produto se manteve dentro dos padrões estabelecidos pela legislação brasileira. A acidez total, compostos fenólicos, parâmetros de cor e ácidos orgânicos reduziram-se durante o armazenamento, contudo, o $\mathrm{pH}$ e o potencial antioxidante aumentaram, durante um ano de estocagem. Assim, concluiu-se que a geleia de araçá é um produto com boas características nutricionais, que apresenta bons níveis de compostos antioxidantes, durante $\mathrm{o}$ armazenamento, e atende às exigências do consumidor moderno, ou seja, praticidade e saudabilidade.

PALAVRAS-CHAVES: Psidium Guineenses Sw.; frutos do Cerrado; compostos fenólicos.

\section{INTRODUCTION}

The Brazilian Savannah presents a great number of edible fruit species which have long been consumed, both in natura and in the form of sweets, desserts, cakes, breads, cookies, jams, and liqueurs (Almeida 1998). Amongst these species, stands out the araçá (Brazilian guava), from the Myrtaceae family, which can be found from the Rio Grande do Sul State, in the South of Brazil, to the Amazon

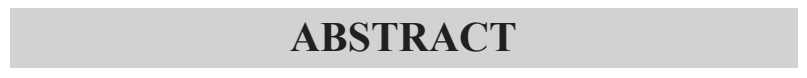

The araçá (Brazilian guava) jam is a promising alternative for expanding the consumption of this fruit, besides adding value to it and making the Brazilian Savannah fruits known. Therefore, this research aimed to study the physical and chemical characteristics of the araça jam, as well as to evaluate the presence and behavior of antioxidant compounds and color, during 12 months of storage. The results obtained for centesimal composition, sugars, fibers, pectin, and consistency showed that the use of araçá was suitable for the jam production, and that the product remained within the standards established by the Brazilian legislation. The total acidity, phenolic compounds, color parameters, and organic acids contents decreased during storage, while the $\mathrm{pH}$ and antioxidant potential increased, during one year of storage. Thus, it was possible to conclude that the araçá jam is a product with good nutritional characteristics, presenting good levels of antioxidant compounds, during storage, and meeting the demands of the modern consumer, i.e. practicality and healthiness.

KEY-WORDS: Psidium guineensis Sw.; Brazilian Savannah fruits; phenolic compounds.

region, in the North of the country, where many native species are grown and show excellent yield.

The araçá, also known as araçaí, araçá-docampo, araçá-mirim, goiaba-da-guiné or araçá-azedo, is a spherical berry, measuring $1.5-4.5 \mathrm{~cm}$ in diameter, with a yellow, whitish-yellow, greenish-yellow or pale yellow color, when ripe, which grows in a small bush (Psidium guineensis Sw.). Its pulp is fleshy, white, mucilaginous, sweet, slightly tart, and aromatic, with numerous small seeds (Manica 2000).

1. Trabalho recebido em abr./2011 e aceito para publicação em dez./2011 (n ${ }^{\circ}$ registro: PAT 13980).

2. Universidade Federal de Goiás, Escola de Agronomia e Engenharia de Alimentos, Goiânia, GO, Brasil. E-mails: damianiclarissa@hotmail.com, flaviocamp@gmail.com.

3. Universidade Federal de Goiás, Faculdade de Farmácia, Goiânia, GO, Brasil. E-mail: asquieri@gmail.com. 4. Universidade Federal de Goiás, Escola de Veterinária e Zootecnia, Goiânia, GO, Brasil. E-mail: moacir@cpa.vet.ufg.br. 5. Universidade Federal de Lavras, Departamento de Ciência de Alimentos, Lavras, MG, Brasil.E-mail: evbvboas@ufla.br. 
The araçá contains water (89.91\%), ash $(0.80 \%)$, malic acid (1.54\%), sugars $(5.54 \%)$, cellulose $(2.55 \%)$, and fat $(0.20 \%)$ (Manica 2000$)$. Franco (1999) pointed out the presence of retinol $(48 \mu \mathrm{g})$, thiamin $(60 \mu \mathrm{g})$, riboflavin $(40 \mu \mathrm{g})$, niacin $(1.3 \mathrm{mg})$, ascorbic acid (326 mg), sugars $(8 \mathrm{~g})$, proteins $(1 \mathrm{~g})$, lipids $(0.2 \mathrm{~g})$, calcium $(14 \mathrm{mg})$, phosphorus $(30 \mathrm{mg})$, iron $(1.05 \mathrm{mg})$, and $37.8 \mathrm{kcal}$ in $100 \mathrm{~g}$ of the fruit. In addition, Andrade et al. (1993) determined its moisture (85-86\%), $\mathrm{pH}(3.0)$, citric acid (1.87\%), ${ }^{\circ}$ Brix (11), sugars $(5.05 \%)$, carotenoids (0.103 mg), and vitamin C (389.34 mg) (100 g sample), although its chemical composition can vary according to rainfall, altitude, climate, and soil, in the regions where it is harvested (Caldeira et al. 2004), and also according to the origin of its genetic material, period of production, and fruit maturation (Bezerra et al. 2006).

Although araçá has been consumed for many years, just a few people have access to this fruit, since it is only found in some regions of the country and in a few months of the year. In order to solve this problem, food technologies, such as the manufacturing of jams, could add value to this fruit, as well as providing its consumption throughout the year, making it available in the whole country.

Jams must present a gelatinous consistency aspect, in a way that, when extracted from their containers, they are able to remain in a semi-solid state, provide elasticity to the touch, and return to their original form, after a slight pressure. Their color and smell must resemble the fruit in its natural state and their flavor should be sweet and semi-acid. Jams must present maximum moisture of $38 \% \mathrm{~m} \mathrm{~m}^{-1}$, minimum soluble solids of $62 \% \mathrm{~m} \mathrm{~m}^{-1}$, and maximum pectin of $2 \% \mathrm{~m} \mathrm{~m}^{-1}$, according to the Brazilian Normative Resolution $\mathrm{n}^{\mathrm{o}} 15$ (Brasil 1978).

Antioxidants are chemical substances that react with free radicals and thus limit their adverse effects on the body. The human body has the ability to produce certain endogenous antioxidants, but most of them come from the food ingested (Borguini \& Torres 2009).

In recent years, natural antioxidants have been publicized extensively in some sectors of industry and medicine, and the therapeutic benefits of fruits, vegetables, and herbs are often associated with the antioxidant capacity.

The prophylactic use of wine, teas, and substances associated with phytoantioxidants are recommended by nutritionists, for preventing cancer, cardiovascular and other chronic diseases. Some examples of phenolic compounds with high antioxidant activity are the flavonoids, tannins, caffeic acid, chlorogenic acid, and ascorbic acid, which are abundant in plants (Blasco et al. 2004). Other important compounds are the anthocyanins and ellagic acid. Anthocyanins are pigments found in plants, within the flavonoids class, which also have antioxidant effects (Manach et al. 2004). Ellagic acid belongs to the hydrolysable tannins group, formed from the hydrolysis of ellagitannins. It is widely found in the human diet, with anticarcinogenic and antimutagenic antioxidant effect (Meyer et al. 1998).

Consumers are currently demanding more convenient and diversified products, that meet the desired flavor, aroma, and color, not neglecting their nutritional quality. Therefore, this study aimed to use the araçá as an ingredient to make jam, thus adding value to this fruit, and to evaluate its nutritional and technological characteristics, as well as how antioxidant compounds and color act during the jam storage.

\section{MATERIAL AND METHODS}

The experiment was carried out in Goiânia, Goiás State, Brazil, in 2010. Araçá fruits were harvested in the Minas Gerais State, Brazil, in 2009. After selection, they were washed, in order to remove surface contamination, rinsed, and submerged in a $100 \mu \mathrm{L}^{-1}$ sodium hypochlorite solution, for 20 minutes. They were then drained and immediately packaged and frozen $\left(-18^{\circ} \mathrm{C}\right)$, until further processing.

Extra type jams, or 50\% fruit and 50\% sugar (Brasil 1978), were made by using $6.0 \mathrm{~kg}$ of fruit juice (previously filtered), $30 \mathrm{~g}$ of pectin, $60 \mathrm{~g}$ of citric acid (amount needed for the juice to reach $\mathrm{pH} 3.2$ ), and $6.2 \mathrm{~kg}$ of sugar, forming a single batch. After checking the acidity and pectin content (fruit peel and pulp), by using chemical analyses, the fruits were processed. The soluble solids content of the juice (peel and pulp) was determined and water was added to reduce it to $20^{\circ}$ Brix. One third of the sugar was then added and the solution was transferred to the concentrator, where it was heated until it began to boil. At this point, one third of the sugar previously mixed with the pectin was added. The remaining sugar was then added to the mixture and it was concentrated to $63^{\circ}$ Brix. Citric acid, diluted in potable water, was then added, 
in order to reduce the $\mathrm{pH}$ to approximately 3.2 , and concentrated to $65^{\circ}$ Brix. The final jam was hot-filled into $150 \mathrm{~g}$ pre-sterilized glass jars, at $85^{\circ} \mathrm{C}$. The glass jars then passed through an exhauster, vacuum sealed, placed upside down for 5 minutes, cooled, and packed into cardboard boxes (away from light), at room temperature (approximately $25^{\circ} \mathrm{C}$ ), for one year.

After completion of the manufacturing process, the araça jams were submitted to chemical and physical evaluation (only at time zero). Additional evaluations for antioxidant compounds, phenolics, $\mathrm{pH}$, total acidity, organic acids, and color $\left(\mathrm{L}^{*}, \mathrm{a}^{*}\right.$, and $\left.\mathrm{b}^{*}\right)$ were carried out in triplicate, every two months, during the year of storage.

The moisture content (oven at $105^{\circ} \mathrm{C}$, for 6 hours), ash (incineration at $550^{\circ} \mathrm{C}$ ), protein ( $\mathrm{N}$ x 6,25), lipids, dietary fiber (enzymaticgravimetric), $\mathrm{pH}$, total acidity, soluble solids, soluble sugars, total sugars, and sucrose were all determined according to AOAC (1997), with results expressed in percentage. The total and soluble pectin contents were determined by a colorimetric method, according to Bitter \& Muir (1962), and the total carbohydrate content according to Dubois et al. (1956), while the total caloric value was estimated in accordance with the Atwater conversion values (Wilson et al. 1982), with results respectively expressed in percentage and kcal.

The mineral contents were determined by using a Varian SpectrAA 110 atomic absorption spectrometer, with wavelength, slot, and gas mixture calibrated specifically for each element. Merck atomic absorption standard ampoules (potassium, sulfur, magnesium, sodium, phosphorus, manganese, copper, iron, zinc, cobalt, and molybdenum), duly diluted with deionized water, were used to construct the calibration curves, with results expressed in $\mathrm{mg} \mathrm{kg}{ }^{-1}$.

The consistency was determined by using a TAXT2 (Stable Microsystems) Texturometer, with a $2.5 \mathrm{~cm}$ diameter cylinder probe. The probe was set to penetrate the jam (4 $\mathrm{mm}$ deep), to minimize wall effects, at a speed of $2 \mathrm{~mm} \mathrm{~s}^{-1}$, to then retract back to the surface, where it waits for $5 \mathrm{~s}$ and repeats the test. The readings were made at three distinct points of each jam package and expressed in Newton.

The organic acids were extracted according to Bazimarakenga et al. (1995), as modified by Silva et al. (2001), and the identification and quantification followed the HPLC (High Performance Liquid
Chromatography) method, by using a Shimadzu CLASS LC 10 chromatograph equipped with a SPDM10A UV detector, at a wavelength of $230 \mathrm{~nm}$, with a C-18 reverse phase column $(150 \mathrm{~mm} \times 4.6 \mathrm{~mm})$. The sample injection volume was $20 \mu \mathrm{L}$, with water containing $0.1 \%$ of phosphoric acid as the mobile phase, and a flux of $1 \mathrm{~mL}$ minute ${ }^{-1}$. Peaks corresponding to each acid (ascorbic, malic, tartaric, acetic, and citric) were identified by using standard retention times for comparison, with results expressed in $\mu \mathrm{g} \mathrm{g}^{-1}$.

The antioxidant potential was determined with the aid of the DPPH method, as described by Brand-Williams et al. (1995) and modified by Borguini \& Torres (2009). The degree of discoloration of the DPPH radical at $517 \mathrm{~nm}$, by the action of the antioxidants, was spectrophotometrically (Shimadzu mod. UV-1601 PC) measured in the ethereal, alcoholic, and aqueous extracts, with a concentration of $0.2 \mathrm{mg} \mathrm{mL}^{-1}$, and results were expressed as DPPH discoloration $100 \mathrm{~g}^{-1}$.

The extraction of alcoholic and aqueous compounds was carried out as described by Genovese et al. (2003), for determining total phenols, by using the Folin-Ciocalteu reagent. The determination of these phenols was described by Zieliski \& Kozowaska (2000), and results were expressed as gallic acid equivalent - GAE (mg $\left.100 \mathrm{~g}^{-1}\right)$.

The color $\left(\mathrm{L}^{*}, \mathrm{a}^{*}\right.$, and $\left.\mathrm{b}^{*}\right)$ was determined with the aid of a Minolta CR-400 colorimeter, according to the CIE system. $L^{*}$ represents lightness or darkness, with values between 0 (completely black) and 100 (totally white); $a^{*}$ presents values between -80 and +100 , where the extremes correspond, respectively, to green and red; and $b^{*}$ may vary from -50 to +70 , with intensity from blue to yellow. The readings were made at three distinct points in each jam package.

A simple completely randomized experimental design (CRD), with three replications, was used, and the influence of seven levels of the factor time $(0$, 2, 4, 6, 8, 10, and 12 months) was evaluated. Each experimental plot consisted of one glass jar containing $150 \mathrm{~g}$ of jam.

The statistical analysis was performed with the aid of the SISVAR program (Ferreira 2000). After applying the variance analysis, polynomial regression models were selected, based on the F test significance for each model tested and also on the coefficient of determination $(p>0,01)$. 


\section{RESULTS AND DISCUSSION}

The results obtained for the chemical and physical composition of the araçá jam at time zero are available in Table 1. The moisture content is within the limits established by the Brazilian legislation (no more than $35 \%$ mass mass $^{-1}$ of extra jam) (Brasil 1978). The protein content was lower than the amount found in fresh fruits $(1.87 \%)$, mainly due to the sugar added during the developing process of the new product. The total carbohydrate content, mainly due to the amount of sugar in the jam formulations ( $6.2 \mathrm{~kg}$ of sugar to $6.0 \mathrm{~kg}$ of fruit juice), increased the caloric value of the jam, concerning the fruit. The lipid content in the pulp, before transformation, was $0.33 \%$, decreasing to $0.18 \%$, in the finished product. This can possibly happen due to oxidation, which converts lipids to acids, ketones, aldehydes, etc. (Fennema 2000).

The levels of reducing sugars were higher than the sucrose ones. This happened because, during the cooking process for the jam manufacturing, the sucrose underwent an inversion process, due to the acid medium, being partly or completely converted into glucose and fructose (invert sugar). This inversion is necessary to prevent crystallization during the process (Lopes 1985).

The main component of the araça jam soluble solids was represented by sugars (64.13\%), followed by the total soluble organic acids, in agreement with the Brazilian legislation (Brasil 1978), which stipulates a minimum of $65^{\circ}$ Brix.

Table 1. Chemical and physical composition (wet weight basis) of araçá jam stored at room temperature, away from light (time zero) (Goiânia, Goiás State, Brazil, 2010).

\begin{tabular}{|c|c|}
\hline Analyses & Mean \\
\hline Moisture (g $\left.100 \mathrm{~g}^{-1}\right)$ & 34.45 \\
\hline Ash $\left(\mathrm{g} 100 \mathrm{~g}^{-1}\right)$ & 0.24 \\
\hline Protein $\left(\mathrm{g} 100 \mathrm{~g}^{-1}\right)$ & 0.91 \\
\hline Lipid $\left(g 100 \mathrm{~g}^{-1}\right)$ & 0.18 \\
\hline 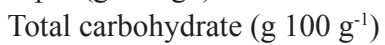 & 69.97 \\
\hline Calories (kcal) & 285.04 \\
\hline Total sugars $\left(\mathrm{g} 100 \mathrm{~g}^{-1}\right)$ & 64.13 \\
\hline Reducing sugars $\left(\mathrm{g} 100 \mathrm{~g}^{-1}\right)$ & 32.39 \\
\hline 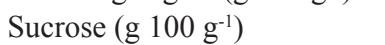 & 31.74 \\
\hline Soluble solids ( ${ }^{\circ} \mathrm{Brix}$ ) & 68.10 \\
\hline Fiber $\left(\mathrm{g} 100 \mathrm{~g}^{-1}\right)$ & 1.18 \\
\hline Total pectin $\left(\mathrm{g} 100 \mathrm{~g}^{-1}\right)$ & 1.00 \\
\hline Soluble pectin $\left(\mathrm{g} 100 \mathrm{~g}^{-1}\right)$ & 0.60 \\
\hline 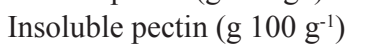 & 0.40 \\
\hline Consistency $(\mathrm{N})$ & 0.83 \\
\hline
\end{tabular}

The fiber content decreased, when compared to the fresh fruit $(4.82 \%)$. That can be explained by the fact that the juice used for processing the jam was filtered (pulping), what removed much of the fiber.

The insoluble pectin content was lower than the soluble one, because, at high temperatures, in an acid medium, the pectin can be hydrolysed and transformed into pectinic and pectic acids.

The jam consistency was $0.83 \mathrm{~N}$, which is linked to its continuity (pectin concentration) and rigidity (sugar and acid).

In the araçá pulp, it was possible to identify the presence of calcium $\left(485 \mathrm{mg} \mathrm{kg}^{-1}\right)$, magnesium (292 $\left.\mathrm{mg} \mathrm{kg}^{-1}\right)$, zinc $\left(2.72 \mathrm{mg} \mathrm{kg}^{-1}\right)$, iron $\left(5.48 \mathrm{mg} \mathrm{kg}^{-1}\right)$, copper (3.2 $\left.\mathrm{mg} \mathrm{kg}^{-1}\right)$, and phosphorus $\left(97.5 \mathrm{mg} \mathrm{kg}^{-1}\right)$.

The ash content reached a mean of $0.24 \%$ and the predominant mineral in the araçá jam was potassium $\left(1,200 \mathrm{mg} \mathrm{kg}^{-1}\right)$, followed by calcium and sulfur (both with $200 \mathrm{mg} \mathrm{kg}^{-1}$ ), and then magnesium (94 mg kg-1), sodium (35 $\mathrm{mg} \mathrm{kg}^{-1}$ ), phosphorus (23 $\mathrm{mg} \mathrm{kg}^{-1}$ ), manganese ( $5 \mathrm{mg} \mathrm{kg}^{-1}$ ), copper (4 mg kg-1), iron $\left(3.4 \mathrm{mg} \mathrm{kg}^{-1}\right)$, zinc $\left(0.75 \mathrm{mg} \mathrm{kg}^{-1}\right)$, cobalt $\left(0.02 \mathrm{mg} \mathrm{kg}^{-1}\right)$, and molybdenum $\left(0.01 \mathrm{mg} \mathrm{kg}^{-1}\right)$. Some lower values, concerning the araçá pulp, can be explained mainly as a result of the juice thinning, before the jam preparation, which also occurred in the evaluation of minerals in other fruit jams, according to Plessi et al. (2007).

The $\mathrm{pH}$, total acidity, and organic acids were influenced by time $(\mathrm{p}>0.01)$ (Figure 1).

The $\mathrm{pH}$ showed a slightly increasing tendency (3.24 to 3.33 ), and consequently the total acidity showed a slightly decreasing tendency $(1.2 \%$ to $1 \%$ ), due to the decrease in organic acids contents, like ascorbic, malic, tartaric, citric, and acetic acids.

The ascorbic acid or vitamin $\mathrm{C}$ content (142.5 $\mu \mathrm{g} \mathrm{g}^{-1}$ for the fresh fruit pulp and $377.5 \mu \mathrm{g} \mathrm{g}^{-1}$ for the skin) decreased to $28.4 \mu \mathrm{g} \mathrm{g}^{-1}$, after the jam manufacturing, due to the oxidation process, which was accelerated by the high temperature used in the gel formation. Ascorbic acid was detected up to the 4th month of storage, when it became undetectable up to the end of the experiment.

A decrease in vitamin $\mathrm{C}$ content was also observed in guava jam stored for three months, according to Jawaheer et al. (2003). These authors concluded that there was a $62.5 \%$ loss, during its processing, reaching more than $70 \%$, during its storage, due to storage temperature and presence of residual $\mathrm{O}_{2}$. After consuming all the oxygen, 
the ascorbic acid can be anaerobically degraded to furfural. Another possible explanation is low moisture content and also its consumption in the Maillard reaction (Giannakourou \& Taoukis 2003).

Malic acid decreased $88.2 \%\left(127.1 \mu \mathrm{g} \mathrm{g}^{-1}\right.$ to $\left.15 \mu \mathrm{g} \mathrm{g}^{-1}\right)$, tartaric acid $93.27 \%\left(52 \mu \mathrm{g} \mathrm{g}^{-1}\right.$ to $\left.3.5 \mu \mathrm{g} \mathrm{g}^{-1}\right)$, citric acid 59.11\% (921 $\mu \mathrm{g} \mathrm{g}^{-1}$ to $\left.376.6 \mu \mathrm{g} \mathrm{g}^{-1}\right)$, and acetic acid decreased during storage $\left(326.8 \mathrm{mg} \mathrm{g}^{-1}\right.$ to $\left.1.25 \mu \mathrm{g} \mathrm{g}^{-1}\right)$. The levels of organic acids found in the fresh fruit were $881.25 \mu \mathrm{g} \mathrm{g}^{-1}$, for citric acid; $761.3 \mu \mathrm{g} \mathrm{g}^{-1}$, for malic acid; and $296.3 \mu \mathrm{g} \mathrm{g}^{-1}$, for tartaric acid. The decrease in the malic and tartaric acids, during the jam manufacturing, may be explained by the evaporation process, during its processing. The increase in the citric acid content, in relation to the fresh fruit, was due to its incorporation
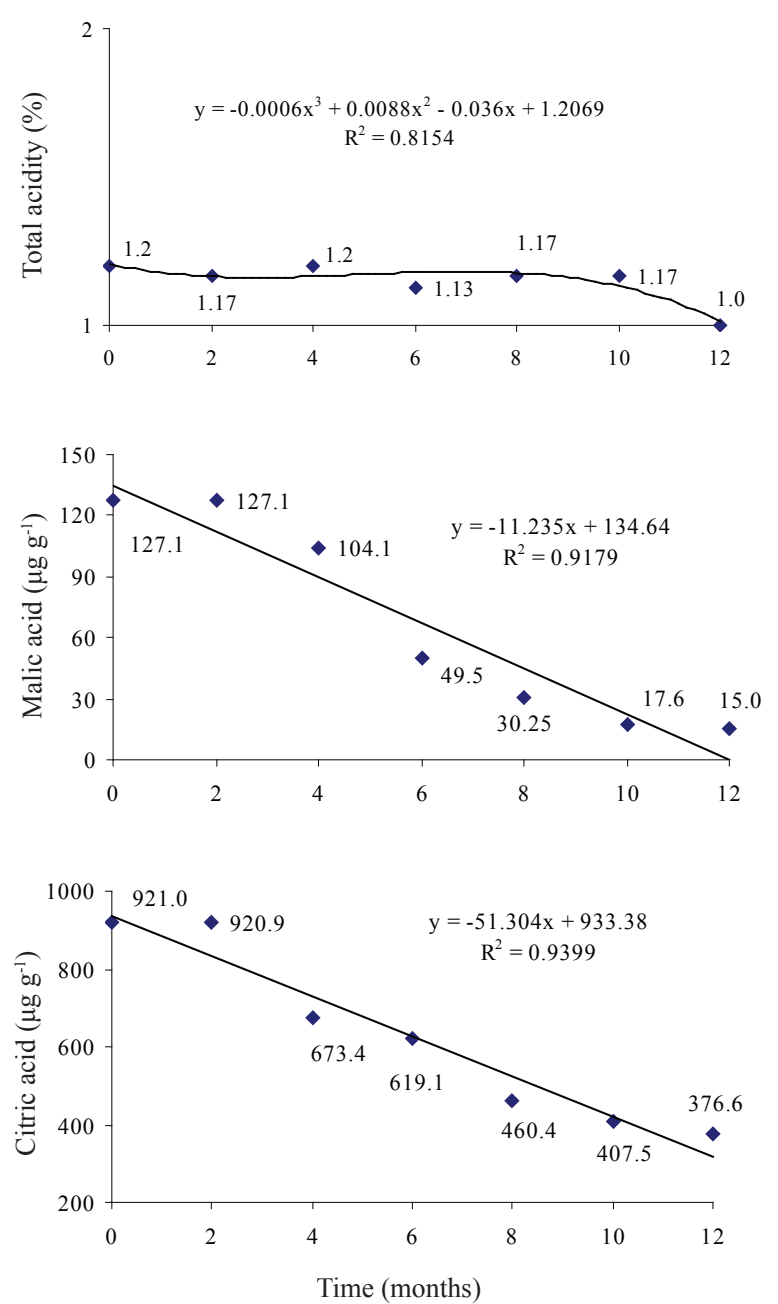

as an ingredient, for the purpose of lowering the $\mathrm{pH}$. In the presence of residual oxygen, or that incorporated into the gel, the alcohol is converted to acetic acid (Snowdon \& Oliver 1996).

Apart from nutrients such as proteins, carbohydrates, lipids, and sugars, the araçá jam provided good amounts of calories and other substances beneficial to health, such as
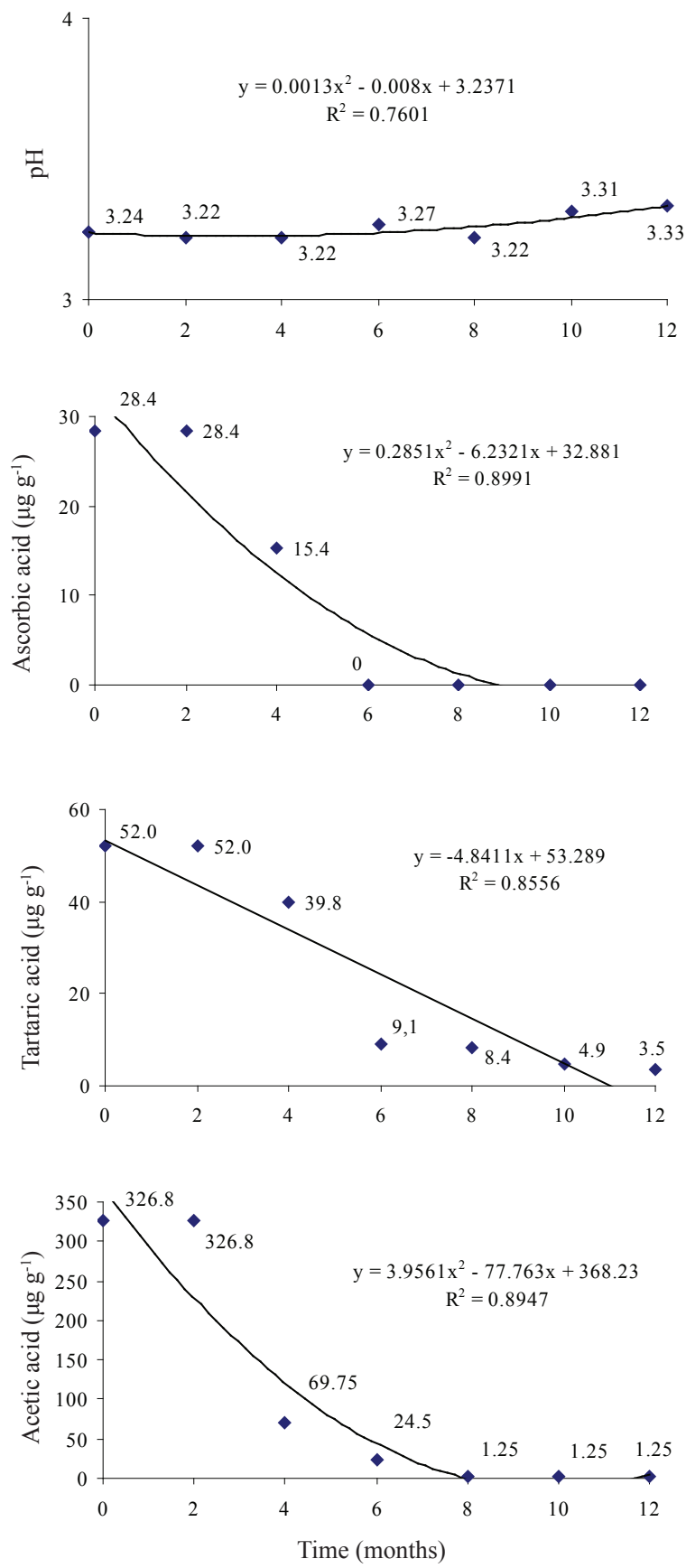

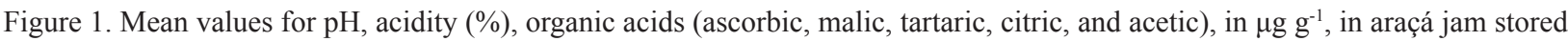
at room temperature $\left(25^{\circ} \mathrm{C}\right)$, away from light, for 12 months (Goiânia, Goiás State, Brazil, 2010). 
antioxidants. These and the phenolic compounds were influenced by time $(p>0.01)$ (Figure 2$)$.

An increase in the antioxidant potential was observed up to the 8th month of storage and then decreased up to the 12th month. The total antioxidant potential increased from $9.28 \%$ to $47.25 \%$ and then decreased to $26.21 \%$. The antioxidant present in the ether extract ranged from $2.37 \%$ to 6.46 , with a maximum of $15.35 \%$; the antioxidant potential in the ethanol extract ranged from $2.39 \%$ to $6.55 \%$, with a maximum of $13.47 \%$; and finally the aqueous antioxidant substances ranged from $4.54 \%$ to $13.2 \%$, with a maximum of $18,43 \%$.

The antioxidant potentials found in the lipids and ethanol were similar, although lower than the one found in the aqueous extract. The presence of different antioxidant compounds in plant tissues, such
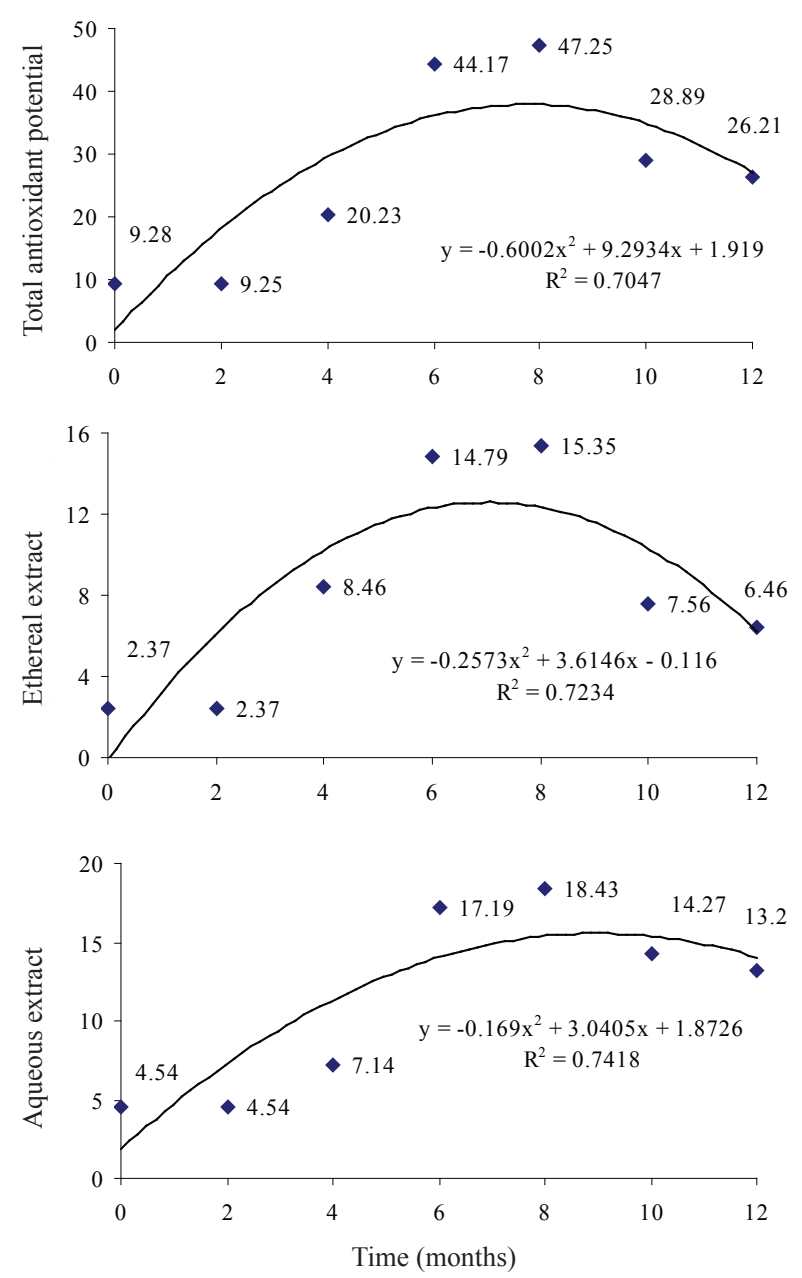

as fruits and vegetables, makes it relatively difficult to measure the antioxidant activity of each component separately. The various solvents certify the maximum solubility of the antioxidants in the sample. The use of three solvents of different polarities, ethyl ether (2:9), ethanol (5.2), and distilled water (9), enables the dissolution of the more polar compounds (aqueous extract), those with intermediate polarity (ethanol extract), and the non-polar ones (ether extract), according to Borguini \& Torres (2009).

Typical compounds that possess antioxidant activity include the class of phenols, phenolic acids and their derivatives, flavonoids, tocopherol, phospholipids, phytic acid, ascorbic acid, pigments, and sterols (Roesler et al. 2007). In addition, Zafrilla et al. (2001) studied the effect of the antioxidant ellagic acid, during the storage of raspberry (Rubus idaeus) jams, and observed that its content doubled with the processing and continued increasing during 6 months of storage, as also occurred with the araçá jam, concerning the antioxidant compounds, probably due to gradual release of ellagic acid, through ellagictannins. The increase in the antioxidant capacity could also have its origin in the products from the Maillard reaction, such as amino reductones, which also show antioxidant effects (Fennema 2000). However, its
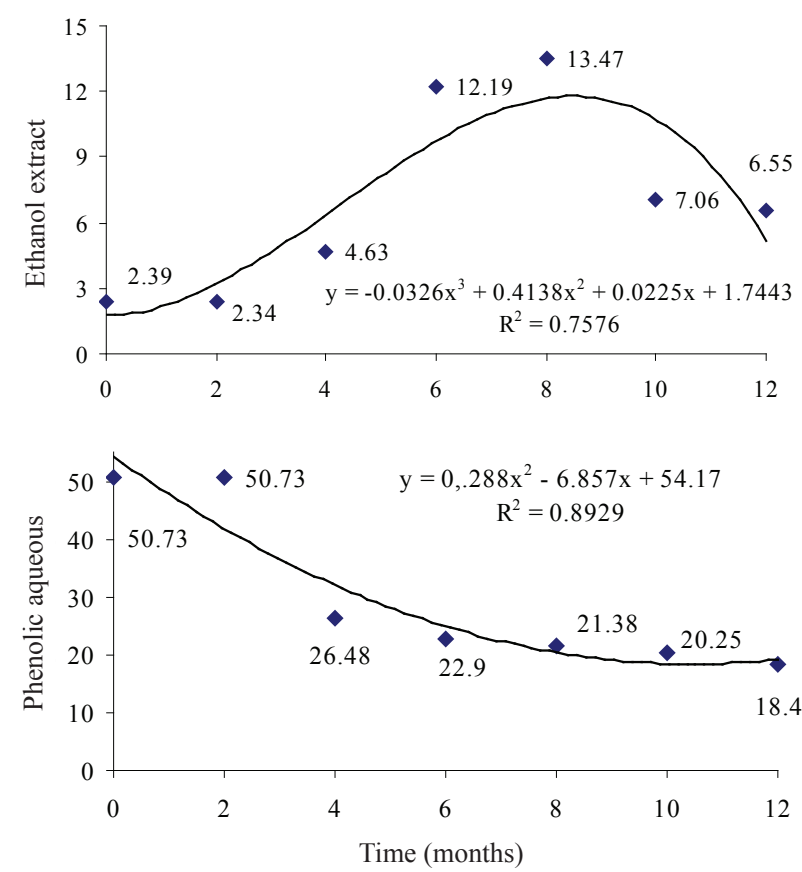

Figure 2. Total antioxidant potential, and ethereal, ethanol and aqueous extract, all expressed as \% of decolorization of the DPPH radical, and phenolic compounds in aqueous medium (gallic acid equivalent mg $100 \mathrm{gg}^{-1}$ ). Standard BHT $0.05 \mathrm{mg} \mathrm{mL}^{-1}=$ $96.27 \%$ and $0.1 \mathrm{mg} \mathrm{mL}^{-1}=100 \%$, in the araçá jam stored at room temperature $\left(25^{\circ} \mathrm{C}\right)$, away from light, for $12 \mathrm{months}$ (Goiânia, Goiás State, Brazil, 2010). 
reduction, at the end of 12 months, could possibly be explained by the degradation of the anthocyanins, as a function of a temperature above $20^{\circ} \mathrm{C}$ (storage was at $25^{\circ} \mathrm{C}$ ), according to a study carried out by Wicklund et al. (2005), to assess the antioxidant activity and color of strawberry jam, during storage. However, it is noteworthy that even decreasing the antioxidants levels at the end of the storage, they reached their highest levels at the end of the experiment.

The phenolic compounds were only found in the aqueous extract, with contents reducing with storage time. At the beginning of the experiment, their

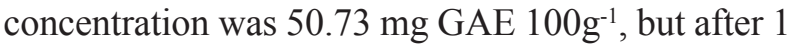

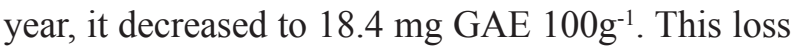
can be explained by the instability of these compounds at temperatures above $23^{\circ} \mathrm{C}$ and close to $40^{\circ} \mathrm{C}$ (temperature conditions to which the araçá jam was
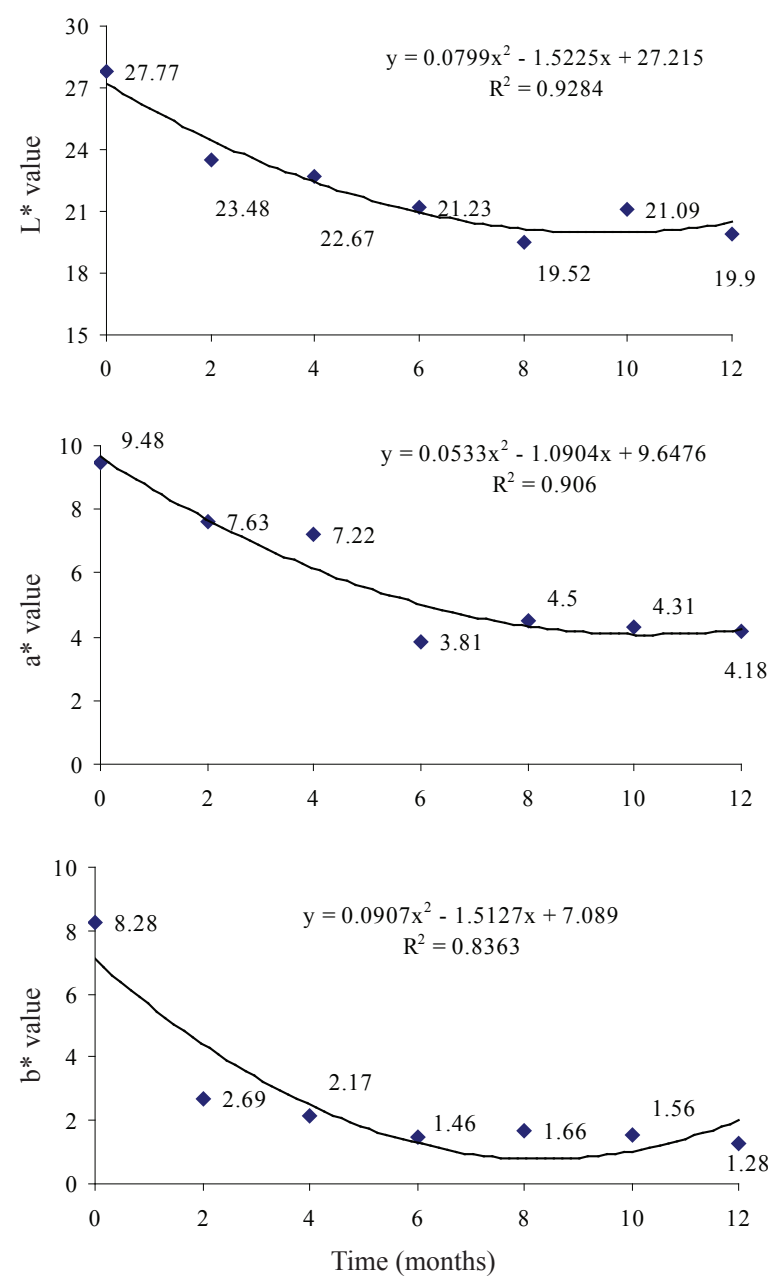

Figure 3. Color parameters ( $\mathrm{L}^{*}, \mathrm{a}^{*}$, and $\left.\mathrm{b}^{*}\right)$ of araçá jam stored at room temperature $\left(25^{\circ} \mathrm{C}\right)$, away from light, for 12 months (Goiânia, Goiás State, Brazil, 2010). stored), according to studies by Chang et al. (2006), to evaluate the effect of storage temperature on the phenolic compounds stability in fruits.

The color parameters $\left(\mathrm{L}^{*}, \mathrm{a}^{*}\right.$, and $\mathrm{b}^{*}$ values) were also reduced by the time factor $(p>0.01)$ (Figure 3). L* ranged from 27.77 to 19.9 , a* from 9.48 to 4.18 , and $b^{*}$ from 8.28 to 1.28 . The $L^{*}$ reduction indicated the darkening of the product, probably due to the Maillard reaction and/or the hydroxymethylfurfural (HMF) formation, during the vitamin $\mathrm{C}$ oxidation. In products with high sugar concentrations, they combine with free amino acids or become part of the protein chains to form dark compounds. At $\mathrm{pH}$ values below 5, there is an intermediate compound that undergoes dehydration, leading to the HMF formation. This actually occurs during heating, i. e. during the jam manufacturing, but also during storage for extended periods. Apart from reducing sugars, the carbonic fraction can originate from lipid oxidation, also feeding the Maillard reaction (Fennema 2000).

Cardoso (2008) studied the color stability of jambo (Syzygium jambos L.) jams stored at $25^{\circ} \mathrm{C}$ and $35^{\circ} \mathrm{C}$, for 180 days, and also observed a $\mathrm{L}^{*}$ and $\mathrm{b}^{*}$ reduction, with darkening of the jam during storage.

\section{CONCLUSIONS}

1. Araçá is a fruit suitable for the manufacturing of jams, representing a possible alternative to add value and expand its use throughout the country.

2. Araçá jam presents low protein and lipid contents, although its fiber content and soluble pectin may help bowel functioning. Its moisture and soluble solids contents are within the standards established by the Brazilian legislation.

3. The antioxidant activity increased during the 12 months of storage, collaborating with a reduction in the free radicals to which people are daily exposed, and, during storage, the araçá jam underwent a darkening process, with a decrease in $\mathrm{L}^{*}, \mathrm{a}^{*}$, and $\mathrm{b}^{*}$ values.

\section{REFERENCES}

ALMEIDA, S. P. de. Cerrado: aproveitamento alimentar. Planaltina: Embrapa, 1998. 
ANDRADE, J. S.; ARAGÃO, C. G.; FERREIRA, S. A. Caracterização física e química dos frutos de araçá-pêra (Psidium acutangulum D.C). Acta Amazonica, Manaus, v. 23, n. 2-3, p. 213-217, 1993.

ASSOCIATION OF OFFICIAL AGRICULTURAL CHEMISTS (AOAC). Official methods of the Association of the Agricultural Chemists. 16. ed. Washington, DC: AOAC, 1997.

BAZIMARAKENGA, B.; SIMARD, R. R.; LEUROX, G. D. Determination of organic acids in oil extracts by ion chromatography. Soil Boilogy and Biochemistry, Elmsford, v. 27, n. 1, p. 349-356, 1995.

BEZERRA, J. E. F. et al. Araçá. In: VIEIRA, R. F. et al. (Eds.). Frutas nativas da região Centro-Oeste do Brasil. Brasília, DF: Embrapa Recursos Genéticos e Biotecnologia, 2006. p. 41-62.

BITTER, V.; MUIR, H. M. A modified uronic acid carbazole reaction. Analisys Biochemistry, New York, v. 4, n. 4, p. 330-334, 1962.

BLASCO, A. J.; GONZALEZ, M. C.; ESCARPA, A. Electrochemical approach for discriminating and measuring predominant flavonoids and phenolic acids using differential pulse voltammetry: towards an electrochemical index of natural antioxidants. Analytica Chimica Acta, New York, v. 511, n. 3, p. 71-81, 2004.

BORGUINI, R. G.; TORRES, E. F. S. Tomatoes and tomato products as dietary sources of antioxidants. Food Reviews International, Madison, v. 25, n. 4. p. 313-325, 2009.

BRAND-WILLIAMS, W.; CUVELIER, M. E.; BERSET, C. Use of a free radical method to evaluate antioxidant activity. Lebensm-Wiss U-Technolology, London, v. 28, n. 1, p. 25-30, 1995.

BRASIL. Agência Nacional de Vigilância Sanitária. Resolução normativa $n .^{\circ} 15$, de 1978. 1978. Disponível em: <http://www.anvisa.gov.br>. Acesso em: 17 mar. 2011.

CALDEIRA, S. D. et al. Caracterização físico-química do araçá (Psidium guineense Sw.) e do tarumã (Vitex cymosa Bert.) do Estado do Mato Grosso do Sul. Boletim do Centro de Pesquisa de Processamento de Alimentos (CEPPA), Curitiba, v. 22, n. 1, p. 145-154, 2004.

CARDOSO, R. L. Estabilidade da cor de geleia de jambo (Eugenia malaccensis L.) sem casca armazenada aos $25^{\circ} \mathrm{C}$ e $35^{\circ} \mathrm{C}$ na presença e ausência de luz. Ciência e Agrotecnologia, Lavras, v. 32, n. 5, p. 1563-1567, 2008.

CHANG, Q. et al. Effect of storage temperature on phenolics stability in hawthorn (Crotaegus pinnatifida var. Major) fruits and a hawthorn drink. Food Chemistry, London, v. 98, n. 1, p. 426-430, 2006.
DUBOIS, M. K. A. et al. Colorimetric method for determination of sugars and related substances. Analytical Chemistry, Washington, DC, v. 28, n. 3, p. 350-355, 1956.

FENNEMA, O. R. Química de los alimentos. 2. ed. Saracoza: Acribia, 2000.

FERREIRA, D. F. Análises estatísticas por meio do SISVAR para Windows versão 4.0. In: REUNIÃO ANUAL DA REGIÃO BRASILEIRA DA SOCIEDADE INTERNACIONAL DE BIOMETRIA, 45., 2000, São Carlos. Resumos... São Carlos, UFSCar, 2000. p. 255-258.

FRANCO, G. Tabela de composição química dos alimentos. 9. ed. São Paulo: Atheneu, 1999.

GENOVESE, M. I. et al. Determinação do conteúdo de fenólicos totais em frutas. Revista Brasileira de Ciências Farmacêuticas, São Paulo, v. 39, n. 3, p. 167-169, 2003.

GIANNAKOUROU, M. C.; TAOUKIS, P. S. Kinetic modeling of vitamin $\mathrm{C}$ loss in frozen green vegetables under variable storage conditions. Food Chemistry, London, v. 83, n. 1, p. 33-41, 2003.

JAWAHEER, B.; GOBURDHUN, D.; RUGGOO, G. Effect of processing and storage of guava into jam and juice on the ascorbic acid content. Plants Foods for Human Nutrition, Dordrecht, v. 58, n. 3, p. 1-12, 2003.

LOPES, R. L. T. Manual para fabricação de geleias. Belo Horizonte: Fundação Centro Tecnológico de Minas Gerais, 1985.

MANACH, C. et al. Polyphenols food sources and bioavailability. American Journal of Clinical Nutrition, Rockville Pike, v. 79, n. 5, p. 727-747, 2004.

MANICA, I. Frutas nativas, silvestres e exóticas 1: técnicas de produção e mercado: abiu, amora-preta, araçá, bacuri, biriba, carambola, cereja-do-rio-grande, jabuticaba. Porto Alegre: Cinco Continentes, 2000.

MEYER, A. S.; HEINONEN, M.; FRANKEL, E. N. Antioxidant interactions of catechin, cyaniding, caffeic acid, quercitin and ellagic on human LDL oxidation. Food Chemistry, London, v. 61, n. 1-2, p. 71-75, 1998.

PLESSI, M.; BERTELLI, D.; ALBASINI, A. Distribution of metals and phenolic compounds as a criterion to evaluate variety of berries related jams. Food Chemistry, London, v. 100, n. 1, p. 419-427, 2007.

ROESLER, R. et al. Atividade antioxidante de frutos do Cerrado. Ciência e Tecnologia de Alimentos, Campinas, v. 27, n. 1, p. 1004-1019, 2007.

SILVA, F. A. et al. Exsudação de ácidos orgânicos em rizosfera de plantas daninhas. Planta Daninha, Viçosa, v. 19, n. 2, p. 193-196, 2001. 
SNOWDON, J. A.; OLIVER, D. O. Microorganism in honey. International Journal of Food Microbiology, Longmont, v. 31, n. 8, p. 1-23, 1996.

WICKLUND, T. et al. Antioxidant capacity and colour of strawberry jam as influenced by cultivar and storage conditions. Food Science and Technology, Zurich, v. 38, n. 1, p. 387-391, 2005.

WILSON, E. D.; SANTOS, A. C.; VIEIRA, E. C. Energia. In: OLIVEIRA, J. E. D.; SANTOS, A. C.; WILSON, E. D. Nutrição básica. São Paulo: Savier, 1982. p. 79-97.
ZAFRILLA, P.; FERRERES, F.; TOMS-BARBERN, A. Effect of processing and storage on the antioxidant ellagic acid derivatives and flavonoids of red raspberry (Rubus idaeus) jam. Journal of Agricultural and Food Chemistry, Washington, DC, v. 49, n. 8, p. 3651-3655, 2001.

ZIELISKI, H.; KOZOWSKA, H. Antioxidant activity and total phenolics in selected cereal grains and their different morphological fractions. Journal of Agricultural and Food Chemistry, Washington, DC, v. 48, n. 11, p. 2008-2016, 2000 . 